\title{
The Effect of Technological Innovations on Environmental Quality in Selected OECD Countries
}

Aslı ÖZPOLAT (https://orcid.org/0000-0002-1769-3654), Gaziantep University, Turkey; ozpolat@ gantep.edu.tr Ferda NAKIPOĞLU-ÖZSOY (https://orcid.org/0000-0002-5593-413X), Gaziantep University, Turkey; nakipoglu@gantep.edu.tr

\section{Seçili OECD Ülkelerinde Teknolojik Yeniliklerin Çevre Kalitesi Üzerine Etkisi}

\begin{abstract}
This study aims to examine the effect of technological innovations on the environmental quality in 1995-2017 for the selected OECD countries and to determine Environmental Kuznets Curve. While carbon emission is the dependent variable, patent applications, GDP per capita, energy use, and urbanization are used as control variables in the model. Second-generation panel analysis has been estimated to examine the link between technological innovations and environmental quality. According to the results obtained, Environmental Kuznets Curve is not valid in selected OECD countries. Technological innovation decreases environmental degradation while energy use and urbanization increase degradations.

Keywords

$$
\text { Environmental Kuznets Curve, Technological Innovation, }
$$
Environmental Degradation.

JEL Classification Codes : $\quad$ K32, O13, O44.

\section{$\ddot{\mathbf{O} z}$}

Bu çalışmada, seçili OECD ülkeleri için 1995-2017 yılları arasında teknolojik yeniliklerin çevre kalitesi üzerindeki etkisinin incelenmesi ve Çevresel Kuznets Eğrisinin belirlenmesi amaçlanmıştır. Karbon emisyonu bağımlı değişken iken, patent başvuruları, kişi başına düşen GSYİH, enerji kullanımı ve kentleşme modelde kontrol değişken olarak kullanılmıştır. Teknolojik yenilikler ve çevresel kalite arasındaki bağlantıyı incelemek için ikinci nesil panel analizi tahmin edilmiştir. Elde edilen sonuçlara göre, Çevresel Kuznets Eğrisi seçili OECD ülkelerinde geçerli değildir. Teknolojik yenilik, çevresel bozulmayı azaltırken, enerji kullanımı ve şehirleşme de bozulmaları artırmaktadır.
\end{abstract}

Anahtar Sözcükler $\quad$ : Çevresel Kuznets Eğrisi, Teknolojik Yenilik, Çevresel Bozulma. 
Özpolat, A. \& F. Nakıpoğlu-Özsoy (2022), "The Effect of Technological Innovations

on Environmental Quality in Selected OECD Countries", Sosyoekonomi, 30(51), 11-31.

\section{Introduction}

Due to the connection of the energy sector with other sectors of the economy, both energy supply and energy demand have an important place in the economy. Energy has an important place in raising the welfare levels of societies and determining the countries' international policies. Therefore, energy is the primary source of economic growth and industrialization (Paul \& Bhattacharya, 2004). Moreover, the rapid change and transformation in the general structure of the economy required more energy use.

According to the United Nations Statistics, the world population, which is 7.78 billion today, is increasing rapidly. 55\% of the population lives in urban areas, according to 2018 data, and it is expected to increase to $60 \%$ in 2030 and to $68 \%$ in 2050. This rapid increase in the population caused the necessary measures to protect the environmental quality (UN, 2018). As stated in some of the studies, it is seen that urban residents tend to consume more than those living in rural areas, and it is observed that approximately $71-76 \%$ of carbon emissions and $67-76 \%$ of global energy use occur in urban areas (Seto et al., 2014; UN, 2017). Rapid urbanization happening worldwide creates problems in meeting basic services such as education, health, transportation, infrastructure, housing, employment, and a clean environment. On the other hand, with the increasing economic activities, fast and incorrect urbanization causes several negative externalities and environmental quality deterioration, such as causing excessive use and unnecessary use of resources.

Technological innovations and R\&D expenditures are also crucial for ensuring energy efficiency and environmental sustainability (Jones, 2002; Fisher-Vanden et al., 2004; Zhou et al., 2010). Although there are approaches to increase energy efficiencies, such as political precaution or controls, there is a direct relationship between energy efficiency and technological innovation. Advanced technological innovations reduce energy use in the economy, increase energy efficiency and lead to more output with less energy input (Zhou et al., 2010; Sohag et al., 2015). Thus, technological innovation increases efficiency in energy use and encourages renewable energy sources. However, there is a contradiction in reducing energy use. Thanks to technological innovations, reducing energy use lowers energy prices; on the other hand, it may cause economic agents who want to benefit from low energy prices to use more energy (Greening et al., 2000). The effectiveness of technological innovation has attracted the attention of governments. It has led policymakers to play an active role in ensuring sustainable economic growth, reducing polluting emissions, and promoting clean energy sources. Patent applications or numbers, one of the most important indicators of technological innovation, also play a crucial role in increasing environmental quality. Therefore, there are some superiorities of using the numbers of patent applications to mitigate environmental degradation: i) Firstly, to contribute to the improvement of environmental quality in the world, large amounts of incentives are given to R\&D investments and patent applications every year. ii) Patent applications may have a determining feature for the technological innovations and carbon emission relationship. iii) On the other hand, patent rights protect technological development (Sandner \& Block, 2011). 
Özpolat, A. \& F. Nakıpoğlu-Özsoy (2022), “The Effect of Technological Innovations on Environmental Quality in Selected OECD Countries", Sosyoekonomi, 30(51), 11-31.

The article tries to find answers to the effects of technological developments on environmental degradation. Considering that OECD countries are industrialized countries, technological developments directly impact carbon emissions. In this case, the significance of the statistical results obtained is essential. In addition, patent applications were used as an indicator of technological development in the study. The main point that distinguishes this study from studies in this field is patent applications as an indicator. In addition, there are many studies on environmental degradation. When the data is used, country group and time dimension are taken into account, and the results differ. The econometric methods and data sets used in this study are also indicators of the difference. Based on this, our motivation depends on the deficiencies of previous studies.

From the point of this view, the study frame is generally prepared as the following: section 1 reviewed the studies and findings on environmental quality, energy use, urbanization, and technological innovations as two-sub sections. Section 3 describes data and methodology. The results are given in Section 4 and based on the results, conclusions and policy recommendations are in section 5.

\section{Literature Review}

In the literature about environmental degradation, empirical studies have extensively focused on the relationship between economic growth, energy consumption, and $\mathrm{CO}_{2}$ emissions (see, for example, Marrero, 2010; Pao \& Tsai, 2010; Sharma, 2011; Asongu, 2017). However, these studies ignored the role of R\&D activities. For this purpose, studies on environmental economics are divided into two parts in the literature section. In the first part, the studies investigating the relationship between economic growth, energy consumption, and environmental pollution are given. In the second part, a literature review will be conducted on the relationship between R\&D activities-economic growth and environmental degradation.

\subsection{Economic Growth, Energy Consumption, and Environmental Pollution}

In studies related to environmental pollution, it is seen that the effects of independent variables on carbon emissions are generally examined. In the literature, environmental degradation is often represented by $\mathrm{CO}_{2}$ emissions. The relationship between energy consumption, total $\mathrm{CO}_{2}$ emissions, and real output has been investigated frequently and is referred to as Environmental Kuznets Curve (EKC) in economic literature. The EKC hypothesis states that emissions will increase to the income threshold and decrease as income increases. Therefore, an inverted-U shape pattern between real output and $\mathrm{CO}_{2}$ emissions addresses a one-way causality relationship from income to emissions (Apergis \& Payne, 2009: 650). There are three effects on the formation of an inverted $U$ shape curve. The first effect is the scale effect, which states that economic growth harms the environment. Accordingly, economic growth causes environmental damages, and greenhouse gas emissions increase. The second effect is the composition effect. Therefore, the composition effect refers that economic growth positively impacts the environment. The final effect is 
Özpolat, A. \& F. Nakıpoğlu-Özsoy (2022), "The Effect of Technological Innovations on Environmental Quality in Selected OECD Countries", Sosyoekonomi, 30(51), 11-31.

the technological effect. Accordingly, economic growth with clean and new energy sources positively affects the environment. Therefore, while the scale effect is valid in the first stage of economic growth, the composition and technological effects are valid in the following periods (Saboori, 2012: 185). Looking at the studies showing the existence of a parabolic relationship between economic growth and carbon emissions, it is seen that Ang (2007) found the inverse U-shaped relationship between economic growth and carbon emissions in France in the 1960-2000 period. Jalil and Mahmud (2009) obtained a parabolic relationship between carbon emissions and economic growth from 1975 to 2005 in China.

In the study of Pao and Tsai (2010), which tested the validity of the EKC hypothesis in BRICS (Brazil, Russia, India, and China), the findings showed that the EKC hypothesis is valid in all three countries except Russia. Jalil and Feridun (2011) probed the association between China's economic growth, energy consumption, and pollution between 1953 and 2006. According to the results of the ARDL approach, $\mathrm{CO}_{2}$ emissions are determined by income and energy consumption in the long run. In addition, it is concluded that the Environmental Kuznets Curve in China is valid. In addition, Sinha and Shahbaz (2018), in their study of the effect of economic growth on carbon emissions, concluded an inverse Ushaped relationship in India from 1971 to 2015. Dong et al. (2018) stated that the EKC hypothesis in China was valid for 1993-2016. Danish et al. (2019) examined the impact of economic growth on carbon emissions in BRICS countries and concluded that the EKC hypothesis is valid in other BRICS countries, except India, in 1990-2015.

On the other hand, Friedl and Getzner (2003) found a cubic relationship between economic growth and carbon emission in Austria in 1960-1999, while He and Richard (2010) concluded a monotonic relationship in Canada during 1948-2004. In addition, AlMulali et al. (2015a) concluded that the EKC hypothesis was not valid in Vietnam in 19812011, while Ahmad and Du (2017) reported a positive relationship between economic growth and carbon emissions in Iran during the period 1971-2011. Murthy and Gambhir (2018) tested the nonlinear relationship between economic growth and India's carbon emissions from 1991-2014. They found an N-shaped relationship between economic growth and carbon emissions, in which the EKC hypothesis was not valid.

Apergis and Payne (2010) examined the relationship between energy consumption, economic output, and $\mathrm{CO}_{2}$ emissions for 11 countries between 1992 and 2004 . According to the study results, a two-way causality relationship from energy consumption to economic output and a one-way causality relationship between $\mathrm{CO}_{2}$, energy consumption, and economic output was obtained in the short term. Therefore, it was concluded that the feedback hypothesis was valid in the study. In addition, a two-way causality relationship between $\mathrm{CO} 2$ emissions and energy consumption in the long term was found in the study. Therefore, the results indicate that energy production and consumption efficiency should be increased. Acaravci and Ozturk (2010) obtained a two-way causality relationship between energy consumption and $\mathrm{CO}_{2}$ emissions in 7 European countries by using ARDL bound test approach. Saidi and Hammami (2015) investigated the relationship between $\mathrm{CO}_{2}$ emissions and energy use in their studies conducted in 58 countries for 1990-2012 and found a positive 
Özpolat, A. \& F. Nakıpoğlu-Özsoy (2022), “The Effect of Technological Innovations on Environmental Quality in Selected OECD Countries", Sosyoekonomi, 30(51), 11-31.

and significant relationship between variables. Adams et al. (2018) indicated that nonrenewable energy positively affected economic growth in their studies for 30 African countries during 1980-2012.

On the other hand, Cai et al. (2018) investigated the relationship between clean energy consumption, economic growth, and $\mathrm{CO}_{2}$ emissions in $\mathrm{G} 7$ countries with the ARDL bounds test approach. There was no cointegration relationship between the variables for Canada, France, Italy, and the UK, while the cointegration relationship was obtained for Germany. Tuna and Tuna (2019), in their study for ASEAN-5 countries, have concluded that there is a positive and significant effect between economic growth and energy consumption. Similarly, Chen et al. (2019), in their studies investigating the relationship between carbon dioxide emissions, renewable and non-renewable energy sources, and economic growth, concluded that non-renewable energy use increased economic growth in the long run. In their study for India, Kang et al. (2019) examined the relationship between renewable and non-renewable energy sources and economic growth. According to the analysis results using the VAR approach, the decrease in carbon dioxide emissions in India leads to a decline in the economic growth rate.

Studies examining the relationship between economic growth and environmental quality with the urbanization dimension are included in the literature. For instance, Iwata et al. (2010), for France, examined whether the Environmental Kuznets Curve was valid and concluded that there was an inverted U-shaped relation between variables. In addition, the effects of energy consumption and urbanization on $\mathrm{CO}_{2}$ emissions were investigated, and the results were statistically insignificant. However, Cole and Neumayer (2004) examined the nexus between urbanization and carbon emissions and reported a positive relationship between variables. Destek and Ozsoy (2015) analysed the impact of energy consumption and urbanization on environmental pollution for Turkey in 1970-2010. They found that energy consumption and urbanization positively related to carbon emissions.

\subsection{R\&D Activities-Economic Growth, and Environment Nexus}

As a well-known that, especially technological development is more important in energy matters and environmental economics literature in terms of combating global warming and climate change; for this reason, when we look at the background of the technological development and environmental quality nexus, we can see three different effects between technological development and environmental quality. The positive impact expresses that technological development has a reducing impact on $\mathrm{CO}_{2}$ emissions. The neutrality hypothesis claims no significant relationship between technological development and environmental pollution (Kocak \& Ulucak, 2019). The last rebound effect shows that energy efficiency increases and leads to less energy consumption thanks to technological developments. However, the decrease in energy consumption leads to a decline in energy prices. Decreasing energy prices increase energy consumption and environmental pollution (Sorrell et al., 2009; Zhang et al., 2015). In studies that examine the effect of technological development on economic growth, it is generally seen that technological development 
Özpolat, A. \& F. Nakıpoğlu-Özsoy (2022), "The Effect of Technological Innovations on Environmental Quality in Selected OECD Countries", Sosyoekonomi, 30(51), 11-31.

affects economic growth positively. For example, Fang (2011) estimated the impact of R\&D expenditures on economic welfare in China for the period from 1978 to 2008 and reported that technological progress contributes a positive influence on economic growth. InglesiLotz (2016) examined the relationship between R\&D expenditures and economic growth for 34 OECD countries during 1990-2010 and noted that R\&D expenditures affect real GDP positively.

While some studies in the literature examine the relationship between R\&D activities and economic growth, some also looked at their impact on the environment. Lantz and Feng (2006) searched the relationship between technological development, economic growth, population, and $\mathrm{CO}_{2}$ emissions for Canada in 1970-2000 and found a significant quadratic nexus between carbon emissions and technology. Tang and Tan (2013) examined the nexus between economic growth, energy prices, electricity consumption, and technology innovation in Malaysia for 1970-2009. The empirical result of the study shows that electricity consumption is negatively affected by energy prices and technological innovation. Sohag et al. (2015) investigated the impact of technological innovation and economic growth on energy use for Malaysia in the years 1980-2012. It is concluded that technological innovation plays an active role in reducing energy use by increasing energy efficiency. In addition, Irandoust (2016) researched the effects of economic growth and technological innovation on renewable energy during 1975-2012 in Nordic countries. According to the result of the study, a unidirectional causality from technological innovation to renewable energy has been identified.

Moreover, Álvarez-Herránz et al. (2017) investigated the relationship between energy innovation and greenhouse gas emissions in 28 OECD countries from 1990 to 2014. They found that advances in energy technologies lead to improved environmental quality. Nikzad and Sedigh (2017) also found that environmental innovations played an important role in minimizing greenhouse gas growth in Canada during 1990-2008. Similarly, Zhang et al. (2017) examined the effect of environmental innovation on $\mathrm{CO}_{2}$ emissions for China's 30 provinces for 2000-2013. They expressed that energy efficiency is most effective in minimizing emissions and improving environmental quality. Yi and Geetha (2017) tested technological innovation and the $\mathrm{CO}_{2}$ emissions nexus in Malaysia from 1971-2013. They found a negative relationship between technology innovation and pollution-causing emissions in the short term. However, there has been no relationship between variables in a long time.

Similarly, Li and Wang (2017) also reported that technological innovation negatively impacts carbon emissions in 95 countries spanning 1996-2007. Moreover, Chen and Lei (2018) studied the nexus between economic growth, technological innovation, and $\mathrm{CO}_{2}$ emissions for 30 global countries from 1980 to 2014. They concluded that technological innovation had more negative effects on pollution in countries with high carbon emissions. Kahouli (2018) investigated the impact of total $\mathrm{R} \& \mathrm{D}$ investments on $\mathrm{CO}_{2}$ emissions during 1990-2016 in Mediterranean countries. The empirical results show that total R\&D investments harm environmental pollution. Ganda (2019) examined the innovation, 
Özpolat, A. \& F. Nakıpoğlu-Özsoy (2022), “The Effect of Technological Innovations on Environmental Quality in Selected OECD Countries", Sosyoekonomi, 30(51), 11-31.

technological investment, and carbon emissions nexus in selected OECD countries 20002014. The study results indicated that R\&D expenditures negatively correlate with carbon emissions. Lin and Zhu (2019) searched the relation between renewable energy technology innovation and carbon emissions in China from 2000 to 2015. According to the linear regression model results, they reported that renewable energy technology innovation harms carbon emissions.

On the other hand, Garrone and Grilli (2010) investigated the impact of public energy R\&D expenditures on carbon intensity in 13 developed countries in the years 1980-2004. They reported that there is not a significant effect between variables. Samargandi (2017) concluded that technological innovation did not effectively reduce carbon emissions in Saudi Arabia in 1970-2014. Similarly, Cheng et al. (2019) examined the effect of innovation on carbon emissions for OECD countries over the 1996-2015 periods. They reported that there is an insignificant relation between innovation and carbon emissions.

In addition, patent applications, which are an indicator of technological development within the scope of research and development activities, also play an important role in increasing environmental quality. Brunnermeier and Cohen (2003) tested the determinants of environmental innovations from 1983 to 1992 for the US and reported a positive relationship between pollution abatement expenditures and environmental patents. Chen and Lei (2018) have investigated technological innovation and carbon emissions in 30 global countries using patent data as a proxy for technological innovation. According to the study results, there is a negative relation between carbon emissions and patents. On the other hand, Ganda (2019) has examined the impact of innovation and technology investment on environmental pollution by using the number of patent families and concluded a positive relationship between carbon emissions and patents in OECD countries. These patents do not play an influential role in reducing carbon emissions.

\section{Methodology}

To study the impact of technological innovation on environmental degradation by using carbon emissions and compare the relative relationship between GDPs per capita, energy use, and urban population, the annual data has been collected from 1995 to 2017 for selected 12 countries (Canada, Denmark, Finland, France, Germany, Japan, South Korea, New Zealand, Sweden, Spain, UK, and the USA). The patent application number is used as an indicator of technological innovation. In line with this, the countries in the model have been selected according to patent application rank.

The panel model is formed as follows:

$$
\operatorname{InCO2} 2_{i, t}=\alpha_{0}+\alpha_{1} \operatorname{In} Y_{i, t}+\alpha_{2} \operatorname{InY}_{i, t}^{2}+\alpha_{3} \operatorname{INY}_{i, t}^{3}+\alpha_{4} \operatorname{InPAT} T_{i, t}+\alpha_{5} \operatorname{InENU_{i,t}}+\alpha_{6} \operatorname{InURB} B_{i, t}+\varepsilon_{i, t}
$$

In the paper, the empirical model is constituted based on the study of Lin and Zhu (2019). Accordingly, in the model, t, i and $\varepsilon_{i, t}$ indicate that period, cross-section, and 
residual term, respectively. Moreover, $\operatorname{InCO} 2_{i, t}$ is the natural $\log$ of carbon emissions, $\operatorname{InPAT}_{i, t}$ is the natural $\log$ of patent applications, $\operatorname{InENU}_{i, t}$ is the natural log of Energy use, $\operatorname{In} Y_{i, t}$ is the natural $\log$ of GDP per capita, $\operatorname{In} Y_{i, t}^{2}$ is the natural $\log$ of GDP per capita square, $\operatorname{In} Y_{i, t}^{3}$ is the natural $\log$ of GDP per capita cube, and $\operatorname{In} U R B_{i, t}$ is the natural $\log$ of financial development index. Carbon emissions is metric tons per capita. Patent applications are worldwide patent applications filed through the Patent Cooperation Treaty; energy use is measured in $\mathrm{kg}$ of oil equivalent per capita; GDP per capita is measured in constant 2010 US\$; urbanization is urban population. All data were sourced from the World Development Indicators 2020 (World Bank). In general, when the literature is evaluated, the coefficients in the model, $\alpha_{3}, \alpha_{4}$, and $\alpha_{5}$ are not certain. Because the validity of the EKC hypothesis can be changed according to sample and period. However, in the study, we expect that inverted-U shaped, therefore the validity of EKC. $\alpha_{2}$ and $\alpha_{6}$ coefficients are expected to be positive and significant. Finally, $\alpha_{1}$ coefficient is expected to be negative and significant.

The analysis has been analysed the impact of technological innovations on ecological degradations. In line with this, the cross-sectional dependence has been investigated using the CD Test. in the panel data analysis, the breakdowns and changes occurring in the units are independent of each other, and the units do not affect each other. Accordingly, the dependency between the units should be investigated at the first stage of the model. To specify the existence of dependence, a cross-sectional dependent test has been estimated by developed by Breush Pagan (1980) and Pesaran (2004). The CD test developed by Pesaran (2004) is calculated as follows:

$$
C D=\sqrt{\frac{2 T}{N(N-1)}}\left(\sum_{i=1}^{N-1} \sum_{j=i+1}^{N} \hat{\rho}_{i j}\right)
$$

In the model, $\mathrm{T}$ represents the time dimension of the panel; $\mathrm{N}$ is the cross-sectional dimension of the panel and $\hat{\rho}_{i j}$ is the binary OLS correlation sample estimate of the remains (Pesaran, 2004:1-7). After determining the cross-section dependency on the panel, the CIPS unit root analysis developed by Pesaran (2007) has been estimated. CIPS unit root analysis is derived from CADF statistic at equation 3.

$$
\Delta y_{i, t}=a_{i}+\rho_{i} y_{i t-1}+\beta_{i} \bar{y}_{t-1}+\sum_{j=0}^{k} \tau_{i j} \Delta y_{i t-1}^{-}+\sum_{j=0}^{k} \delta_{i j} y_{i t-1}+\varepsilon_{i, t}
$$


The deterministic term $a_{i}$ in the equation refers to the number of lags $\mathrm{k}$ and $y_{t}$ indicates the cross-sectional average of time. The CIPS unit root model created accordingly is as follows:

$$
C I P S=\left(\frac{1}{N}\right) \sum_{i=1}^{N} t_{i}(N, T)
$$

In the study, Westerlund Error Correction Test (2007) and Westerlund DurbinHausman Test (2008) have been estimated to determine the long-term relationship between variables. Within the scope of Westerlund (2007) cointegration analysis, there is no cointegration hypothesis, and alternative hypotheses are formed as two different tests as the average group and panel test. At this stage, four cointegration test statistics $\left(G_{\alpha}, G_{t}, P_{\alpha}, P_{t}\right)$ were created according to the error correction model. According to the analysis, the variables must be stationary in I (1). In Westerlund Durbin-Hausman Cointegration (2008) analysis, variables do not need to be equally stable. In this method, two separate test statistics are calculated as groups and panels $\left(D H_{g}, D H_{p}\right)$. While panel statistics $\left(D H_{p}\right)$, it is expressed by group statistics $\left(D H_{g}\right)$. The statistics are as follows:

$$
D H_{g}=\sum_{i=1}^{n} \hat{S}_{i}\left(\tilde{\phi}_{i}-\hat{\phi}_{i}\right)^{2} \sum_{t=2}^{T} \hat{e}_{i t-1}^{2} D H_{p}=\hat{S}_{n}(\tilde{\phi}-\hat{\phi})^{2} \sum_{i=1}^{n} \sum_{t=2}^{T} \hat{e}_{i t-1}^{2}
$$

FMOLS (Fully Modified Ordinary Least Square) estimator developed by Pedroni (2000) has been used as a cointegration estimator to estimate coefficients of variables. FMOLS Panel estimator formulated as $\hat{\beta}_{G F M}=N^{-1} \sum_{i=1}^{N} \beta_{F M i}^{*}$. Finally, the study conducted the Bootstrap Granger Causality Test (Konya, 2016) panel causality test.

Bootstrap Granger Causality Test is a test that gives statistically more meaningful results in cross-section dependency and heterogeneity conditions. The test is estimated by considering the cross-section dependency and heterogeneity between the units that make up the panel. Estimation of the model is based on SUR (seemingly unrelated regression) method, and the Wald test is used to estimate the direction of causality. In addition, as stated in Bootstrap Granger Causality Test, it does not require a pre-test such as unit root and cointegration before causality analysis. Bootstrap Granger Causality Test panel causality test is formulated as follows:

$$
\begin{aligned}
& C O 2_{1, t}=\alpha_{1,1}+\sum_{i=1}^{l y_{1}} \beta_{1,1, i} C O 2_{1, t-i}+\sum_{i=1}^{l x_{1}} \delta_{1,1, i} P A T_{k, 1, t-i}+\varepsilon_{1,1, t} \\
& C O 2_{2, t}=\alpha_{1,2}+\sum_{i=1}^{l y_{1}} \beta_{1,2, i} C O 2_{2, t-i}+\sum_{i=1}^{l x_{1}} \delta_{1,2, i} P A T_{k, 2, t-i}+\varepsilon_{1,2, t}
\end{aligned}
$$


and

$$
\begin{aligned}
& P A T_{k, 1, t}=\alpha_{2,1}+\sum_{i=1}^{l y_{2}} \beta_{2,1, i} C O 2_{1, t-i}+\sum_{i=1}^{l x_{2}} \delta_{2,1, i} P A T_{k, 1, t-i}+\varepsilon_{2,1, t} \\
& P A T_{k, N, t}=\alpha_{2, N}+\sum_{i=1}^{l y_{2}} \beta_{2, N, i} C O 2_{N, t-i}+\sum_{i=1}^{l x_{2}} \delta_{2, N, i} P A T_{k, N, t-i}+\varepsilon_{2, N, t}
\end{aligned}
$$

While expressing $\mathrm{CO}_{2}$, carbon emissions, PAT, technological innovation in equations; $\mathrm{N}$ refers to the number of units in the panel and the $\mathrm{T}$ time interval. Granger causality is expressed as follows:

- If any country in the panel $\gamma_{1, i}$ is not equal to zero but $\beta_{2, i}$ is equal to zero, there is one-way causality from PAT to $\mathrm{CO} 2$.

- If $\gamma_{1, i}$ is equal to zero but $\beta_{2, i}$ is not equal to zero, there is a one-way Causality from $\mathrm{CO} 2$ to PAT.

- If neither $\gamma_{1, i}$ nor $\beta_{2, i}$ is equal to zero, there is bidirectional Causality among variables.

- If both $\gamma_{1, i}$ and $\beta_{2, i}$ is equal to zero, there is no Causality among variables.

Before the results and discussion, the summary of descriptive statistics with the average of the variables of selected OECD countries has been given in Table 1. According to statistics, carbon emissions range from 0.705 in Sweden to 1.253 in the USA. The highest value belongs to the USA (5.307) for technological innovation, and the lowest value is in New Zealand (3.175). When variations are evaluated, South Korea has the highest variations for technological innovation. 
Table: 1

Descriptive Statistics

\begin{tabular}{|c|c|c|c|c|c|c|}
\hline Countries & & INCO & INPAT & INENU & INY & INURB \\
\hline \multirow[t]{4}{*}{ Canada } & Mean & 1.203 & 3.623 & 3.903 & 4.640 & 7.417 \\
\hline & Maximum & 1.232 & 3.742 & 3.927 & 4.708 & 7.473 \\
\hline & Minimum & 1.175 & 3.385 & 3.882 & 4.539 & 7.357 \\
\hline & Std. Dev. & 0.016 & 0.088 & 0.012 & 0.057 & 0.035 \\
\hline \multirow[t]{4}{*}{ Denmark } & Mean & 0.938 & 3.189 & 3.533 & 4.756 & 6.672 \\
\hline & Maximum & 1.133 & 3.273 & 3.620 & 4.797 & 6.704 \\
\hline & Minimum & 0.734 & 3.091 & 3.449 & 4.691 & 6.648 \\
\hline & Std. Dev. & 0.109 & 0.049 & 0.047 & 0.028 & 0.281 \\
\hline \multirow[t]{4}{*}{ Finland } & Mean & 1.022 & 3.270 & 3.807 & 4.632 & 6.643 \\
\hline & Maximum & 1.135 & 3.411 & 3.853 & 4.694 & 6.672 \\
\hline & Minimum & 0.888 & 3.100 & 3.752 & 4.503 & 6.616 \\
\hline & Std. Dev. & 0.071 & 0.090 & 0.027 & 0.054 & 0.017 \\
\hline \multirow[t]{4}{*}{ France } & Mean & 0.733 & 4.146 & 3.603 & 4.595 & 7.690 \\
\hline & Maximum & 0.791 & 4.168 & 3.633 & 4.633 & 7.729 \\
\hline & Minimum & 0.645 & 4.094 & 3.563 & 4.530 & 4.649 \\
\hline & Std. Dev. & 0.048 & 0.020 & 0.023 & 0.029 & 0.026 \\
\hline \multirow[t]{4}{*}{ Germany } & Mean & 0.985 & 4.674 & 3.603 & 4.604 & 7.794 \\
\hline & Maximum & 1.036 & 4.713 & 3.628 & 4.671 & 7.805 \\
\hline & Minimum & 0.939 & 4.580 & 3.577 & 4.541 & 7.780 \\
\hline & Std. Dev. & 0.027 & 0.026 & 0.016 & 0.039 & 0.006 \\
\hline \multirow[t]{4}{*}{ Japan } & Mean & 0.955 & 5.506 & 3.582 & 4.642 & 8.036 \\
\hline & Maximum & 0.986 & 5.584 & 3.611 & 4.685 & 8.066 \\
\hline & Minimum & 0.922 & 5.413 & 3.535 & 4.606 & 7.990 \\
\hline & Std. Dev. & 0.014 & 0.059 & 0.028 & 0.022 & 0.030 \\
\hline \multirow[t]{4}{*}{ South Korea } & Mean & 0.991 & 5.020 & 3.645 & 4.269 & 7.592 \\
\hline & Maximum & 1.066 & 5.223 & 3.733 & 4.417 & 7.622 \\
\hline & Minimum & 0.870 & 4.704 & 3.506 & 4.081 & 7.547 \\
\hline & Std. Dev. & 0.058 & 0.170 & 0.070 & 0.106 & 0.023 \\
\hline \multirow[t]{4}{*}{ New Zealand } & Mean & 0.860 & 3.175 & 3.629 & 4.509 & 6.554 \\
\hline & Maximum & 0.911 & 3.333 & 3.658 & 4.576 & 6.617 \\
\hline & Minimum & 0.808 & 3.000 & 3.607 & 4.426 & 6.497 \\
\hline & Std. Dev. & 0.033 & 0.084 & 0.016 & 0.046 & 0.034 \\
\hline \multirow[t]{4}{*}{ Sweden } & Mean & 0.705 & 3.444 & 3.735 & 4.686 & 6.893 \\
\hline & Maximum & 0.848 & 3.625 & 3.766 & 4.575 & 6.869 \\
\hline & Minimum & 0.573 & 3.297 & 3.688 & 4.575 & 6.869 \\
\hline & Std. Dev. & 0.089 & 0.124 & 0.024 & 0.056 & 0.023 \\
\hline \multirow[t]{4}{*}{ Spain } & Mean & 0.789 & 3.448 & 3.449 & 4.465 & 7.530 \\
\hline & Maximum & 0.883 & 3.560 & 3.512 & 4.509 & 7.571 \\
\hline & Minimum & 0.696 & 3.311 & 3.391 & 4.375 & 7.479 \\
\hline & Std. Dev. & 0.061 & 0.073 & 0.042 & 0.038 & 0.035 \\
\hline \multirow[t]{4}{*}{ UK } & Mean & 0.894 & 4.239 & 3.528 & 4.581 & 7.692 \\
\hline & Maximum & 0.962 & 4.343 & 3.588 & 4.633 & 7.739 \\
\hline & Minimum & 0.734 & 4.123 & 3.441 & 4.486 & 7.657 \\
\hline & Std. Dev. & 0.070 & 0.063 & 0.053 & 0.042 & 0.027 \\
\hline \multirow[t]{4}{*}{ USA } & Mean & 1.253 & 5.307 & 3.872 & 4.670 & 8.375 \\
\hline & Maximum & 1.307 & 5.470 & 3.906 & 4.727 & 8.426 \\
\hline & Minimum & 1.164 & 5.028 & 3.832 & 4.583 & 8.313 \\
\hline & Std. Dev. & 0.047 & 0.135 & 0.026 & 0.039 & 0.034 \\
\hline \multirow[t]{4}{*}{ Panel } & Mean & 0.944 & 4.087 & 3.657 & 4.588 & 7.407 \\
\hline & Maximum & 1.307 & 5.584 & 3.927 & 4.797 & 8.426 \\
\hline & Minimum & 0.573 & 3.006 & 3.391 & 4.081 & 6.497 \\
\hline & Std. Dev. & 0.170 & 0.827 & 0.141 & 0.313 & 0.565 \\
\hline
\end{tabular}

\section{Empirical Results}

In this part, empirical findings have been discussed. At the first stage of the analysis, the Cross-Section Dependence (CD) and homogeneity tests were estimated. After determining Cross Section Dependence, CIPS unit root test, Westerlund cointegration test, and Konya causality test have been estimated. The results are shown in Table 2. No crosssectional dependence is not accepted according to the all-test results. It means a shock that occurs in an individual of the panel can affect the other individuals. Moreover, the 
homogeneity test results show that a country in the panel has a specific heterogeneity. Therefore, the existence of cross-sectional dependence and heterogeneity among countries is accepted.

Table: 2

Cross-sectional Dependency and Homogeneity

\begin{tabular}{lcc}
\hline & & Statistics \\
\hline CD & 21.060 & 0.000 \\
Homogeneity & & 0.000 \\
$\tilde{\Delta}$ & 7.252 & 0.000 \\
$\tilde{\Delta}_{a d j}$ & 7.777 & \\
\hline
\end{tabular}

For cointegration analysis to be performed after this stage, variables must be integrated at first degree. To evaluate the cointegration analysis results comparatively, two cointegration analyses have been used in the study. While Westerlund ECM analysis requires the variables to be integrated at I (1), for Westerlund's DH analysis, variables are not required to be equally stable. In this context, CIPS unit root analysis was performed. CIPS unit root test results are given in Table 3. According to the results obtained, all variables are first-degree difference stationary; all series are integrated at I (1).

Table: 3

\section{CIPS Unit Root Test Results}

\begin{tabular}{|c|c|c|c|c|}
\hline \multirow[t]{3}{*}{ Variables } & \multicolumn{4}{|c|}{ CIPS } \\
\hline & \multicolumn{2}{|c|}{ Level } & \multicolumn{2}{|c|}{ First } \\
\hline & Constant & Constant \& Trend & Constant & Constant \&Trend \\
\hline INCO & -2.010 & $-2.730^{* *}$ & $-3.761^{* * * *}$ & $-3.536^{* * * *}$ \\
\hline INY & -1.741 & -1.858 & $-2.515^{* *}$ & $-2.594 *$ \\
\hline INEU & -1.977 & $-2.076 * *$ & $-4.133 * * *$ & $-4.286 * * *$ \\
\hline INUR & -1.425 & -1.311 & -1.657 & $-3.104 * * *$ \\
\hline INPAT & -1.469 & $-2.237 * *$ & $-2.810 * * *$ & $-3.032 * * *$ \\
\hline
\end{tabular}

Note: critical values for constant: $* 10 \% ;-2.11 ; * * 05 ;-2.22, * * * \% 1 ;-2.45$, critical values for constant and trend: $* 10 \% ;-2.65 ; * * \% 5 ;-2.77, * * * \% 1 ;-3.33$.

After this stage, the long-term relationship between $\mathrm{CO}_{2}$ emissions, GDP per capita, energy use, patent applications, urbanization, and energy use has been investigated. The existence of a long-term relationship was estimated by Westerlund's ECM Cointegration and Westerlund DH Cointegration analysis. The results are given in Table 4.

Table: 4

Cointegration Test Results

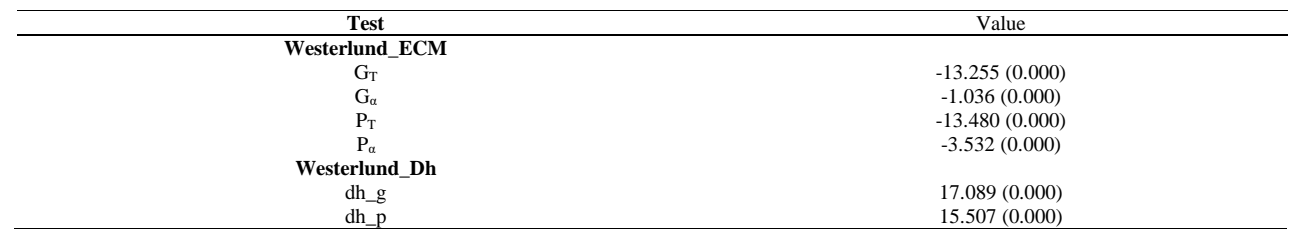


Westerlund Cointegration Test is analysed according to 4 test statistics $\left(G_{\alpha}, G_{t}, P_{\alpha}, P_{t}\right)$ with normal distribution. Of these tests, $\mathrm{G} \alpha$ and Gt represent the group estimate, $\mathrm{P} \alpha$ and $\mathrm{Pt}$ represent the unit estimate. According to the results, all test results support a cointegration relationship. In addition, according to the results of Westerlund DH Cointegration analysis, the presence of a long-term relationship between the variables has been accepted. Finally, FMOLS cointegration estimator was used in the study.

Table: 5

Cointegration Estimators Test Results

\begin{tabular}{cc}
\hline Variables & FMOLS \\
\hline INY & $-0.1328^{* * *}$ \\
INY2 & $-0.1148 * *$ \\
INY3 & $0.0099^{* *}$ \\
INEU & $0.7534 * * *$ \\
INUR & $0.1329 * * *$ \\
INPAT & $-0.0260^{* * * *}$ \\
\hline
\end{tabular}

Prob. Value; *, 10\%; **,\%5; ***,\%1.

When the results in Table 5 are examined, Patent applications harm $\mathrm{CO}_{2}$ emissions. Accordingly, patent applications used as an indicator of technological innovation create environmental improvement. Therefore, technological development has a reducing impact on $\mathrm{CO}_{2}$ emissions in selected countries. The result obtained is similar to Li and Wang (2017), Chen and Lei (2018), and Kahouki (2018). It is seen that energy use is meaningful and positively affects $\mathrm{CO}_{2}$ emissions. The main reason can be that economic growth requires high energy demand. A positive and significant relationship was obtained between urbanization and total $\mathrm{CO}_{2}$ emissions. Urbanization is evaluated in increasing population density in cities because of labour migration from the village to the town. Therefore, the population density in the cities reveals the result of excess energy demand, and the results obtained in similar to Neumayer (2004) and Destek and Ozsoy (2015). Finally, the validity of the Environmental Kuznets Curve was examined. The existence of a U relationship between total $\mathrm{CO}_{2}$ emissions and per capita income is obtained. Therefore, Environmental Kuznets Curve is invalid in these sectors. Figure 1 shows the graphical results of the study. 
Figure: 1

\section{Graphical Results}

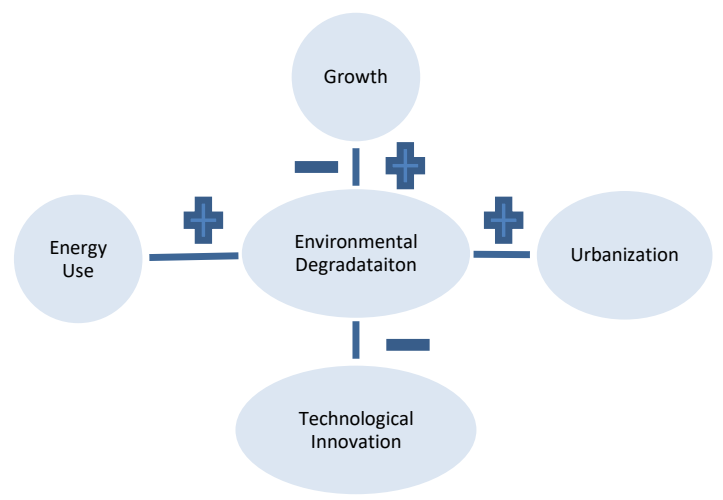

The causality relationship between $\mathrm{CO}_{2}$ and patent applications was also investigated for each country in the study. The findings are included in Table 6.

Table: 6

Bootstrap Granger Causality Test

\begin{tabular}{|c|c|c|c|c|c|c|c|c|}
\hline \multirow[t]{3}{*}{ Country } & \multicolumn{4}{|c|}{$\mathrm{H}_{\mathrm{o}}$ : Inpat does not cause Inco } & \multicolumn{4}{|c|}{$\mathrm{H}_{\mathrm{o}}$ : Inco does not cause Inpat } \\
\hline & \multirow[t]{2}{*}{ Statistics } & \multicolumn{3}{|c|}{ Critical Values } & \multirow[t]{2}{*}{ Statistics } & \multicolumn{3}{|c|}{ Critical Values } \\
\hline & & $\% 1$ & $\% 5$ & $\% 10$ & & $\% 1$ & $\% 5$ & $\% 10$ \\
\hline Canada & 2.777 & 15.194 & 7.048 & 4.203 & $17.240 * * *$ & 12.422 & 10.781 & 8.068 \\
\hline Denmark & 0.573 & 10.578 & 5.555 & 3.171 & $4.783^{* *}$ & 5.957 & 2.393 & 2.048 \\
\hline Finland & 4.098 & 34.416 & 15.976 & 11.128 & 0.813 & 46.296 & 25.315 & 20.268 \\
\hline France & $15.129 *$ & 21.914 & 14.521 & 12.601 & 0.007 & 9.288 & 6.534 & 6.017 \\
\hline Germany & 1.700 & 47.874 & 31.283 & 27.157 & $2.631^{*}$ & 6.826 & 3.638 & 2.207 \\
\hline Japan & 1.996 & 15.600 & 12.014 & 8.967 & 2.246 & 14.109 & 7.048 & 3.931 \\
\hline South Korea & 5.121 & 92.104 & 75.209 & 56.475 & 0.457 & 101.060 & 67.483 & 57.266 \\
\hline New Zealand & 1.681 & 102.438 & 80.967 & 52.615 & 16.469 & 34.589 & 25.470 & 19.110 \\
\hline Sweden & 6.641 & 51.314 & 38.050 & 26.579 & 1.028 & 31.253 & 21.046 & 19.901 \\
\hline Spain & $41.172 * * *$ & 26.314 & 15.576 & 13.783 & $14.695^{* * *}$ & 12.858 & 8.359 & 7.096 \\
\hline UK & 2.880 & 33.741 & 25.064 & 18.979 & 1.122 & 34.228 & 21.206 & 16.458 \\
\hline United State & 11.183 & 49.601 & 35.336 & 30.544 & 0.949 & 6.498 & 5.102 & 2.868 \\
\hline
\end{tabular}

Note: $\% 1, \% 5$ and $\% 10$ indicate that respectively $* * *, * *, *$.

According to the results presented, while there is a unidirectional causality from $\mathrm{CO}_{2}$ to a patent application in Canada and Denmark, a unidirectional causality from patent application capita to carbon emissions in France has been obtained. Finally, there is a unidirectional causality between carbon emissions and patent applications in Spain. According to these results, the increase in $\mathrm{CO}_{2}$ in Canada and Denmark triggers technological research on pollution. But it is not sufficient. In France, however, the rise in pollution does not sufficiently affect the technical analysis in this field. While it is seen that technological research gives results in Spain, in other countries with meaningless results, it can be thought that technological research does not yield satisfactory results on pollution. 
Özpolat, A. \& F. Nakıpoğlu-Özsoy (2022), “The Effect of Technological Innovations

on Environmental Quality in Selected OECD Countries", Sosyoekonomi, 30(51), 11-31.

\section{Conclusion}

The current study aims to search the effect of technological innovations on environmental degradations and compare the relationship between energy use, growth, and urbanization from 1995 to 2017 in selected OECD countries. For this purpose, the relationship among variables is examined with second generations panel data methodologies: the Westerlund cointegration test and Bootstrap Granger Causality Test. According to FMOLS test panel results, technological innovations decrease carbon emissions. Increased patent applications indicate that technological innovations positively contribute to environmental quality. However, energy use, GDP per capita, and urbanization increase environmental degradation.

The following policies can be improved to minimize environmental degradation from the empirical results.

- The negative effect of technological innovation on environmental degradation expresses the importance of using technological innovations to increase energy efficiency.

- Establishing industrial policies related to technological innovation and directing these innovations to energy-intensive sectors can be effective.

- Providing incentives and financial supports for companies working on technological innovation can accelerate the development in this area.

- Increasing the environmental degradation of energy is due to the properties of the energy sources used. In this context, renewable energy sources that reduce carbon emissions will positively impact ecological quality.

- Innovative and R\&D studies should reduce pollution without making any sectoral differences.

- Considering environmental degradation in creating industrial policies of countries will have a reducing effect on emissions.

- Sectoral policies can support technological developments.

- The policies can be improved by making cost-benefit analyses, increasing green technology investment, and disseminating practices such as carbon tax.

- Minimizing pollution also requires social and cultural transformation. Therefore, education policies should include activities that will ensure this transformation.

- Being included in International environmental agreements such as the Paris Agreement and fulfilling the necessary obligations may also reduce the global effects of environmental degradation.

\section{References}

Acaravc1, A. \& I. Ozturk (2010), "On the Relationship Between Energy Consumption, CO2 Emissions and Economic Growth in Europe”, Energy, 35(2010), 5412-5420.

Adams, S. et al. (2018), "Renewable and Non-renewable Energy, Regime Type and Economic Growth", Renew. Energy, 125, 755-767. 
Ahmad, N. \& L. Du (2017), "Effects of Energy Production and CO2 Emissions on Economic Growth in Iran: ARDL Approach", Energy, 123, 521-537.

Al-Mulali, U. et al. (2015a), "Investigating the Environmental Kuznets Curve Hypothesis in Vietnam", Energy Policy, 76, 123-131.

Al-Mulali, U. et al. (2015b), "Investigating the Environmental Kuznets Curve (EKC) Hypothesis by Utilizing the Ecological Footprint as an Indicator of Environmental Degradation", Ecol Indic, 48, 315-323.

Al-Mulali, U. et al. (2015c), "The Global Move Toward Internet Shopping and its Influence on Pollution: An Empirical Analysis”, Environ Sci Pollut Res, 22(13), 9717-9727.

Álvarez-Herránz, A. et al. (2017), "Energy Innovations-GHG Emissions Nexus: Fresh Empirical Evidence from OECD Countries", Energy Policy, 101, 90-100.

Ang J.B. (2007), “CO2 Emissions, Energy Consumption, and Output in France”, Energy Policy, 35, 4772-4778.

Apergis, N. \& J.E. Payne (2009), "CO2 Emissions, Energy Usage, and Output in Central America”, Energy Policy, 37(8), 3282-3286.

Apergis, N. \& J.E. Payne (2010), “A Panel Study of Nuclear Energy Consumption and Economic Growth”, Energy Econ., 32(3), 545-549.

Aşıc1, A.A. \& S. Acar (2016), "Does Income Growth Relocate Ecological Footprint?”, Ecological Indicators, 61, 707-714.

Asongu, S.A. et al. (2017), "Environmental degradation, ICT and Inclusive Development in SubSaharan Africa", Energy Policy, 111, 353-361.

Atil, A. et al. (2019), "Factors Influencing CO2 Emission in China: A Nonlinear Autoregressive Distributed Lags Investigation", MPRA Paper No: 91190.

Aydın, C. et al. (2019), "Is the Ecological Footprint Related to the Kuznets Curve a Real Process or Rationalizing the Ecological Consequences of the Affluence? Evidence from PSTR Approach", Ecological Indicators, 98, 543-555.

Bastida, L. et al. (2019), "Exploring the role of ICT on Household Behavioral Energy Efficiency to Mitigate Global Warming", Renewable and Sustainable Energy Reviews, 103, 455-462.

Bekaroo, G. et al. (2016), "Impacts of ICT on the Natural Ecosystem: A Grass Root Analysis for Promoting Socio-Environmental Sustainability”, Renewable and Sustainable Energy Reviews, 57, 1580-1595.

Breusch, T.S. \& A.R. Pagan (1980), “The Lagrange Multiplier Test and Its Applications to Model Specification in Econometrics", The Review of Economic Studies, 47(1), 239-253.

Brunnermeier, S.B. \& M.A. Cohen (2003), "Determinants of Environmental Innovation in US Manufacturing Industries", Journal of Environmental Economics and Management, 45(2), 278-293.

Cai, Y. et al. (2018), "Nexus Between Clean Energy Consumption, Economic Growth and CO2 Emissions", Journal of Cleaner Production, 182, 1001-1011.

Chavanne, X. et al. (2015), "Electricity Consumption of Telecommunication Equipment to Achieve a Tele-meeting", Apply Energy, 137, 273-281.

Chen, W. \& Y. Lei (2018), “The Impacts of Renewable Energy and Technological Innovation on Environment-Energy-Growth Nexus: New Evidence from a Panel Quantile Regression", Renewable Energy, 123, 1-14. 
Chen, Y. et al. (2019), "CO2 Emissions, Economic Growth, Renewable and Non-renewable Energy Production and Foreign Trade in China", Renew. Energy, 131, 208-216.

Cheng, C. et al. (2019), "The Impact of Renewable Energy and Innovation on Carbon Emission: An Empirical Analysis for OECD Countries”, Energy Procedia, 158, 3506-3512.

Cho, Y. et al. (2007), "The Impact of ICT Investment and Energy Price on Industrial Electricity Demand: Dynamic Growth Model Approach”, Energy Policy, 35, 4730-4738.

Cole, M.A. \& E. Neumayer (2004), "Examining the Impact of Demographic Factors on Air Pollution", Population and Environment, 26(1), 5-21.

Coroama V.C. et al. (2012), "Effects of Internet-Based Multiple-Site Conferences on Greenhouse Gas Emissions", Telematics and Informatics, 29, 362-74.

Danish-Baloch, M.A. et al. (2019), "Effect of Natural Resources, Renewable Energy and Economic Development on CO2 Emissions in BRICS Countries", Science of The Total Environment, 678, 632-638.

Destek, M.A. \& F.N. Ozsoy (2015), "Relationships Between Economic Growth, Energy Consumption, Globalization, Urbanization, and Environmental Degradation in Turkey", International Journal of Energy and Statistics, 3(04), 1550017.

Destek, M.A. et al. (2018), “Analyzing the Environmental Kuznets Curve for the EU Countries: The Role of Ecological Footprint", Environmental Science and Pollution Research, 25(29), 29387-29396.

Dong, K. et al. (2018), "CO2 Emissions, Economic Growth, and the Environmental Kuznets Curve in China: what roles can nuclear energy and Renewable Energy Play?", Journal of Cleaner Production, 196, 51-63.

Dumitrescu, E.I. \& C. Hurlin (2012), "Testing for Granger Non-Causality in Heterogeneous Panels", Econ. Model., 29, 1450-1460.

Elliot, S. (2011), “Transdisciplinary Perspectives on Environmental Sustainability: A Resource base and Framework for IT-Enabled Business Transformation", MIS Quarterly, 35(1), 197 236.

Erdmann, L. \& L.M. Hilty (2010), "Scenario Analysis; Exploring the Macroeconomic Impacts of Information and Communication Technologies on Greenhouse Gas Emissions", Journal Industrial Ecology, 14, 826-43.

Fang, Y. (2011), "Economic Welfare Impacts from Renewable Energy Consumption: The China Experience", Renewable and Sustainable Energy Reviews, 15(9), 5120-5128.

Fettweis, G. \& E. Zimmermann (2008), "ICT Energy Consumption-Trends and Challenges", The1 1th International Symposium on Wireless Personal Multimedia Communications (WPMC2008), 2, 6.

Fisher-Vanden, K. et al. (2004), "What is Driving China's Decline in Energy Intensity?", Resource and Energy Economics, 26(1), 77-97.

Friedl, B. \& M. Getzner (2003), "Determinants of CO2 Emissions in a Small Open Economy", Ecological Economics, 45(1), 133-148.

G7 ICT and Industry Ministers' Declaration (2017), Making the Next Production Revolution Inclusive, Open and Secure, Italy, $<$ https://Teamdigitale.Governo.It/Upload/Docs/2017/10/Declaration_And_Annexes_Fina 1_26_09_2017.Pdf>, 23.08.2019. 
Ganda, F. (2019), “The Impact of Innovation and Technology Investments on Carbon Emissions in Selected Organisation for Economic Co-operation and Development Countries", Journal of Cleaner Production, 217, 469-483.

Garrone, P. \& L. Grilli (2010), "Is There a Relationship Between Public Expenditures in Energy R\&D and Carbon Emissions per GDP? An Empirical Investigation", Energy Policy, 38, $5600-5613$

Gesi (2012), Smart 2020: Enabling the Low Carbon Economy in the Information Age, <https://www.Theclimategroup.Org/Sites/Default/Files/Archive/Files/Smart2020Report. Pdf $>$, 23.08.2019.

Global Footprint Network (2019), National Footprint Accounts, Ecological Footprint, <http://data.footprintnetwork.org>, 23.08.2019.

Gombiner, J. (2011), “Carbon Foot Printing the Internet”, The Journal of Sustainable Development, $5(1), 119-124$.

Greening, L.A. et al. (2000), "Energy Efficiency and Consumption-the Rebound Effect-a Survey", Energy Policy, 28(6-7), 389-401.

Hassan, S.T. et al. (2018), "Economic Growth, Natural Resources, and Ecological Footprints:

Evidence from Pakistan", Environmental Science and Pollution Research, 26(3), 29292938.

He, J. \& P. Richard (2010), "Environmental Kuznets Curve for CO2 in Canada", Ecological Economics, 69(5), 1083-1093.

Higon, D. et al. (2017), "ICT and Environmental Sustainability: A Global Perspective", Telematics and Informatics, 34, 85-95.

Inglesi-Lotz, R. (2016), "The Impact of Renewable Energy Consumption to Economic Growth: A Panel Data Application", Energy Economics, 53, 58-63.

IPCC (2018), Global Warming of $1.5^{\circ} \mathrm{C}$ Report, <https://Www.Ipcc.Ch/Site/Assets/Uploads/Sites/2/2019/06/SR15_Full_Report_High_R es.Pdf $>$, 23.08.2019.

Irandoust, M. (2016), "The Renewable Energy-Growth Nexus with Carbon Emissions and Technological Innovation: Evidence from the Nordic Countries”, Ecological Indicators, 69, 118-125.

Ishida, H. (2015), "The Effect of ICT Development on Economic Growth and Energy Consumption in Japan", Telematics and Informatics, 32, 79-88.

ITU (2019), World Telecommunication/ICT Indicators Database, <https://Www.Itu.Int/En/ITUD/Statistics/Pages/Publications/Wtid.Aspx>, 23.08.2019.

Iwata, H. et al. (2010), "Empirical Study on the Environmental Kuznets Curve for CO2, in France: The Role of Nuclear Energy", Energy Pol., 38(8), 4057-4063.

Jalil, A. \& M. Feridun (2011), "The Impact of Growth, Energy and Financial Development on the Environment in China: a cointegration analysis”, Energy Economics, 33, 284-291.

Jalil, A. \& S.F. Mahmud (2009), "Environmental Kuznets Curve for CO2 Emissions: a Cointegration Analysis for China", Energy Policy, 37, 5167-5172.

Jones, A. (2002), “An Environmental Assessment of Food Supply Chains: A Case Study on Dessert Apples", Environmental Management, 30(4), 560-576. 
Özpolat, A. \& F. Nakıpoğlu-Özsoy (2022), “The Effect of Technological Innovations on Environmental Quality in Selected OECD Countries", Sosyoekonomi, 30(51), 11-31.

Kahouli, B. (2018), "The Causality Link Between Energy Electricity Consumption, CO2 Emissions, R\&D Stocks and Economic Growth in Mediterranean Countries (MCs)", Energy, 145, 388-399.

Kang, H.S. et al. (2019), “The Dynamic Relationships among CO2 emissions, Renewable and NonRenewable Energy Sources, and Economic Growth in India: Evidence from TimeVarying Bayesian VAR Model", Structural Change and Economic Dynamics, 50 (2019), 90-101.

Khan D.N. et al. (2018), "The Level of ICT on CO2 Emissions in Emerging Economies: Does the Level of Income Matters?", Environmental Science and Pollution Research, 25(23), 22850-22860.

Koçak, E. \& Z.Ş. Ulucak (2019), "The Effect of Energy R\&D Expenditures on CO2 Emission Reduction: Estimation of the STIRPAT Model for OECD Countries", Environmental Science and Pollution Research, 26(14), 14328-14338.

Kónya, L. (2006), "Exports and Growth: Granger Causality Analysis on OECD Countries with a Panel Data Approach", Economic Modelling, 23(6), 978-992.

Lee, J.W. \& T. Brahmasrene (2014), "ICT, CO2 Emissions and Economic Growth: Evidence from a Panel of ASEAN", Global Economic Review, 43, 93-109.

Li, M. \& Q. Wang (2017), "Will Technology Advances Alleviate Climate Change? Dual Effects of Technology Change on Aggregate Carbon Dioxide Emissions", Energy Sustain. Dev., 41, 61-68.

Lin, B. \& J. Zhu (2019), “The Role of Renewable Energy Technological Innovation on Climate Change: Empirical Evidence from China", Science of the Total Environment, 659, 15051512.

Lin, B. \& J. Zhu (2019), "The Role of Renewable Energy Technological Innovation on Climate Change: Empirical Evidence from China", Science of the Total Environment, 659, 15051512.

Marrero, G.A. (2010), "Greenhouse Gases Emissions, Growth and the Energy Mix in Europe", Energy Economics, 32(6), 1356-1363.

Matthews, H.S. et al. (2002), "Energy Implications of Online Book Retailing in the United States and Japan", Environ Impact Asses, 22(5), 493-507.

Moyer, J.D. \& B.B. Hughes (2012), “Icts: do They Contribute to Increased Carbon Emissions?”, Technological Forecasting and Social Change, 79, 919-31.

Mrabet, Z. \& M. Alsamara (2017), "Testing the Kuznets Curve Hypothesis for Qatar: a Comparison between Carbon Dioxide and Ecological Footprint", Renew Sust Energ Rev, 70, 13661375.

Murthy, K.V. et al. (2018), “Analyzing Environmental Kuznets Curve and Pollution Haven Hypothesis in India in the Context of Domestic and Global Policy Change", Australasian Accounting, Business and Finance Journal, 12(2), 134-156.

Nikzad, R. \& G. Sedigh (2017), "Greenhouse Gas Emissions and Green Technologies in Canada", Environmental Development, 24, 99-108.

OECD (2010), Greener and Smarter, ICTS, the Environmental and Climate Change Report.

Ozturk, I. et al. (2016), "Investigating the Environmental Kuznets Curve Hypothesis: The Role of Tourism and Ecological Footprint", Environ Sci Pollut Res, 23(2), 1916-1928. 
Özpolat, A. \& F. Nakıpoğlu-Özsoy (2022), "The Effect of Technological Innovations on Environmental Quality in Selected OECD Countries", Sosyoekonomi, 30(51), 11-31.

Pao, H. \& C.M. Tsai (2010), “CO2 Emissions, Energy Consumption and Economic Growth in BRIC Countries”, Energy Policy, 38, 7850-7860.

Paul, S. \& R.N. Bhattacharya (2004), "CO2 Emission from Energy Use in India: A Decomposition Analysis", Energy Policy, 32(5), 585-593.

Pesaran, M.H. (2004), "General Diagnostic Tests for Cross Section Dependence in Panels", Cambridge Working Papers in Economics 0435, Faculty of Economics, University of Cambridge.

Raheem, I.D. et al. (2019), "The Role of ICT and Financial Development on CO2 Emissions and Economic Growth", African Governance and Development Institute Working Paper, WP/19/058.

Room, J. (2002), “The Internet and the New Energy Economy”, Resources, Conservation and Recycling, 36, 197-210.

Saboori, B. et al. (2012), "Economic Growth and CO2, Emissions in Malaysia: a Cointegration Analysis of the Environmental Kuznets Curve”, Energy Pol., 51(4), 184-191.

Sadorsky, P. (2012), "Information Communication Technology and Electricity Consumption in Emerging Economies", Energy Policy, 48, 130-136.

Saidi, K. \& S. Hammami (2015), "The Impact of CO2 Emissions and Economic Growth on Energy Consumption in 58 Countries", Energy Rep, 1, 62-70.

Samargandi, N. (2017), "Sector Value Addition, Technology and CO2 Emissions in Saudi Arabia", Renewable and Sustainable Energy Reviews, 78, 868-877.

Sandner, P.G. \& J. Block (2011), “The market value of R\&D, patents, and trademarks”, Res Policy, 40(7), 969-985.

Seto, K. et al. (2014), "Human Settlements, Infrastructure and Spatial Planning”, in: O. Edenhofer et al. (eds.), Climate Change 2014: Mitigation of Climate Change, Contribution of Working Group III to the Fifth Assessment Report of the Intergovernmental Panel on Climate Change (IPCC, Geneva), (923-1000), Cambridge UK/New York: Cambridge University Press.

Shabani, Z. \& R. Shahnazi (2019), "Energy Consumption, Carbon Dioxide Emissions, Information and Communications Technology, and Gross Domestic Product in Iranian Economic Sectors: A Panel Causality Analysis", Energy, 169, 1064-1078.

Sharma, S.S. (2011), "Determinants of Carbon Dioxide Emissions: Empirical Evidence from 69 Countries", Applied Energy, 88(1), 376-382.

Sinha, A. \& M. Shahbaz (2018), "Estimation of Environmental Kuznets Curve for CO2 Emission: Role of Renewable Energy Generation in India", Renewable Energy, 119, 703-711.

Sohag, K. et al. (2015), "Dynamics of Energy Use, Technological Innovation, Economic Growth and Trade Openness in Malaysia", Energy, 90, 1497-1507.

Sorrell, S. et al. (2009), “Empirical Estimates of the Direct Rebound Effect: A Review”, Energy Policy, 37, 1356-1371.

Takase, K. \& Y. Murota (2004), “The Impact of IT Investment on Energy: Japan and US Comparison in 2010", Energy Policy, 32, 1291-1301.

Tang, C.F. \& E.C. Tan (2013), "Exploring the Nexus of Electricity Consumption, Economic Growth, Energy Prices and Technology Innovation in Malaysia", Applied Energy, 104, 297-305. 
Toffel, M.W. \& A. Horvath (2004), "Environmental Implications of Wireless Technologies: News Delivery and Business Meetings", Environmental Science and Technology, 38, 2961-70.

Tuna, G. \& V.E. Tuna (2019), "The Asymmetric Causal Relationship between Renewable and NonRenewable Energy Consumption and Economic Growth in the ASEAN-5 Countries", Resource Policy, (62), 114-124.

United Nations (2017), "Urban Environment Related Mitigation Benefits and Co-Benefits of Policies, Practices and Actions for Enhancing Mitigation Ambition and Options for Supporting their Implementation", Framework Convention on Climate Change, United Nations publication, FCCC/TP/2017/2.

United Nations (2018), World Urbanization Prospects: The 2018 Revision, ST/ESA/SER.A/420.

Webb, M. et al. (2008), "SMART 2020: Enabling the Low Carbon Economy in the Information Age", Climate Group, 1(1), 1.

Westerlund, J. (2007), "Testing for Error Correction in Panel Data", Oxford Bulletin of Economics and Statistics, 69(6), 709-748.

Westerlund, J. (2008), "Panel Cointegration Tests of the Fisher Effect", Journal of Applied Econometrics, 23, 193-233.

Yii, K.J. \& C. Geetha (2017), "The Nexus between Technology Innovation and CO2 Emissions in Malaysia: Evidence from Granger Causality Test”, Energy. Procedia., 105, 3118-3124.

Zhang, C. \& C. Liu (2015), "The Impact of ICT Industry on CO2 Emissions: A Regional Analysis in China", Renewable and Sustainable Energy Reviews, 44, 12-19.

Zhang, Y.J. et al. (2015), "Direct Energy Rebound Effect for Road Passenger Transport in China: A Dynamic Panel Quantile Regression Approach”, Energy Policy, 87, 303-313.

Zhang, Y.J. et al. (2017), "Can Environmental Innovation Facilitate Carbon Emissions Reduction? Evidence from China”, Energy Policy, 100, 18-28.

Zhou, N. et al. (2010), "Overview of Current Energy-Efficiency Policies in China", Energy Policy, $38(11), 6439-6452$. 
Özpolat, A. \& F. Nakıpoğlu-Özsoy (2022), "The Effect of Technological Innovations on Environmental Quality in Selected OECD Countries", Sosyoekonomi, 30(51), 11-31. 